\title{
Species Action Plans for the conservation of seabirds in the Mediterranean Sea: Audouin's gull, Balearic shearwater and Mediterranean shag*
}

\author{
UMBERTO GALLO-ORSI \\ BirdLife International, European Division Office, Droevendaalsesteeg 3a, PO Box 127, NL-6700 AC Wageningen, \\ The Netherlands. E-mail: Umberto.Galloorsi@birdlife-europa.nl
}

\begin{abstract}
SUMMARY: BirdLife International has so far developed Action Plans for 37 bird species. The plans, although not legally binding, have been approved by the Ornis Committee (EU DG Environment) and most of them have also been endorsed by the Standing Committee of the Bern Convention. Three of the species covered by the SAPs are Mediterranean seabirds: Audouin's gull (Larus audouinii), Balearic shearwater (Puffinus mauretanicus) and Mediterranean shag (Phalacrocorax aristotelis desmarestii). The documents, which have been produced through a participatory process involving tens of experts across the range of the taxa, provide information on the biology, ecology and threats, but the most important feature is the list of specific objectives and actions which are ranked according to their priority and urgency. Alongside actions addressing species-specific conservation needs, such as site protection and management, a number of activities aimed at the conservation of these species are common and refer to wide policies such as land-use planning, fishery, tourist development and pollution control. The documents represent the most up-to-date and scientifically-based source of information for planning and implementing conservation activities across the Mediterranean, to be implemented by both governmental and non governmental organisations.
\end{abstract}

Key words: Audouin's gull, Balearic shearwater, shag, Action Plan, conservation, Mediterranean.

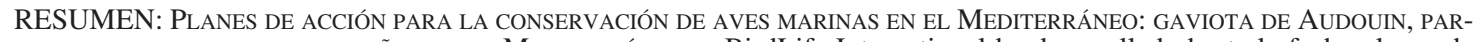
DELA BALEAR Y CORMORAN MOÑUDO DEL MEDITERRÁNEO. - BirdLife International ha desarrollado hasta la fecha planes de acción para 37 especies de aves. Los planes, aunque no son vinculantes, han sido aprobados por el comité Ornis de la Unión Europea y la mayor parte de ellos ha sido ratificados por el comité permanente de la convención de Berna. Tres de las especies que cuentan con planes de acción son aves marinas: la gaviota de Audouin (Larus audouinii), la pardela balear (Puffinus mauretanicus) y el cormorán moñudo del Mediterráneo (Phalacrocorax aristotelis desmarestii). Los documentos, generados a través de un proceso participativo en el que han colaborado decenas de expertos, proporcionan información sobre la biología, ecología y amenazas de las especies aunque el aspecto más importante es el listado de objetivos específicos y acciones que aparecen ordenadas según prioridad y urgencia. Los planes sugieren acciones de amplio espectro, comunes a todas las especies, tales como una correcta ordenación territorial, de la pesca, del desarrollo turístico y el control de la contaminación, junto con acciones referentes a las necesidades de conservación de cada especie, tales como protección y gestión de los lugares de cría. Estos documentos representan la fuente de información más actualizada y con más base científica de que disponemos para llevar a cabo acciones de conservación en el Mediterráneo por parte de las organizaciones gubernamentales o no gubernamentales.

Palabras clave: gaviota de Audouin, pardela balear, cormorán moñudo, planes de acción, conservación, Mediterráneo. 
INTRODUCTION: THE CONSERVATION STRATEGY OF BIRDLIFE INTERNATIONAL

BirdLife International Strategy is based on 4 pillars: species, sites, habitat and people.

The 'Species' pillar has been developed through the identification of the priority species at a global level (Collar et al., 1994, BirdLife International, 2000), and at a European level (Tucker and Heath, 1994). For all priority species in Europe (SPEC 1 see below) Species Action Plans have been produced. The 'Site' work has led to the identification of 3,619 IBA in Europe (Heath and Evans, 2000) and it is currently under development in Africa (with 4 national inventories already produced), Asia and the Americas. 'Habitat' work covers a wide range of activities from actions upon the EU policies (Agriculture, Rural development, Forestry, etc.) to activities at a national level or demonstration projects based on conservation strategies, as in the publication "Habitat for birds in Europe" (Tucker and Evans, 1997). 'People', our last but not least pillar, includes communication, awareness and development of the partnership, which currently covers more than 100 countries or territories world-wide.

The four pillars are of course tightly connected and the conservation of congregatory species necessarily involves the conservation of key sites, while dispersed species are better conserved by a habitatoriented approach. Often the two go together since many species can fall into both categories at different times of the year. This is typically the case of seabirds, which are concentrated during breeding but are less so outside breeding time and sites.

\section{THE SPECIES PROGRAMME}

Following the identification of the globally threatened species, a survey of the conservation status of 514 European species led to the identification of 278 Species of European Conservation Concern (SPEC), which have been ranked in 4 classes (Tucker and Heath, 1994).

For 23 globally threatened species (SPEC 1), BirdLife International has developed Species Action Plans which have been approved by the Ornis Committee (EU DG Environment) and endorsed by the Bern Convention Standing Committee and by the Bonn Convention and published by the Council of Europe (Heredia et al., 1996). Subsequently 24 further Species Action Plans or Management State- ments have been produced to cover the whole list of species (SPEC 2 and 3) and subspecies which have been identified by the Ornis Committee as priority for funding under the LIFE Nature instrument.

Three of the species covered by the SAPs are Mediterranean seabirds: Audouin's gull (Larus audouinii) [SPEC 1], Balearic shearwater (Puffinus mauretanicus) and Mediterranean shag (Phalacrocorax aristotelis desmarestii). Each action plan was based on the inputs from a workshop with the participation of experts from the European range states and 2-3 drafts were circulated to a wide audience from the research and conservation community.

\section{THE ROLE OF THE SAPS}

1. Action Plans provide a framework for action for governments and national governmental agencies, BirdLife partners, other NGOs and scientists.

2. Action Plans, endorsed through intergovernmental agreements, provide an official basis for actions.

3. Action Plans are a reference for fundraising.

The plans are intended as tools to identify priority measures for conservation action to halt and restore the populations of the most endangered bird species in Europe, and should assist EU member states in fulfilling their obligations under the Birds Directive.

\section{STRUCTURE OF THE ACTION PLANS}

Each plan consists of three main sections. Part 1 deals with background information about status, ecology, threats and current conservation measures. Threats have been rated according to the following categories:

- Critical, a factor that could lead to the extinction of the species or sub-species in 20 years or less.

- High, a factor that could lead to a decline of more than $20 \%$ of the population in 20 years or less.

- Medium, a factor that could lead to a decline of less than $20 \%$ of the population in 20 years or less.

- Low, a factor that is only likely to affect the species or sub-species at a local level.

- Unknown, a factor that is likely to affect the species or sub-species but it is unknown to what extent.

Part 2 includes the aims and generic objectives of the plan. The objectives are grouped under the fol- 
TABle 1. - Overview of the threats according to the Species Action Plans.

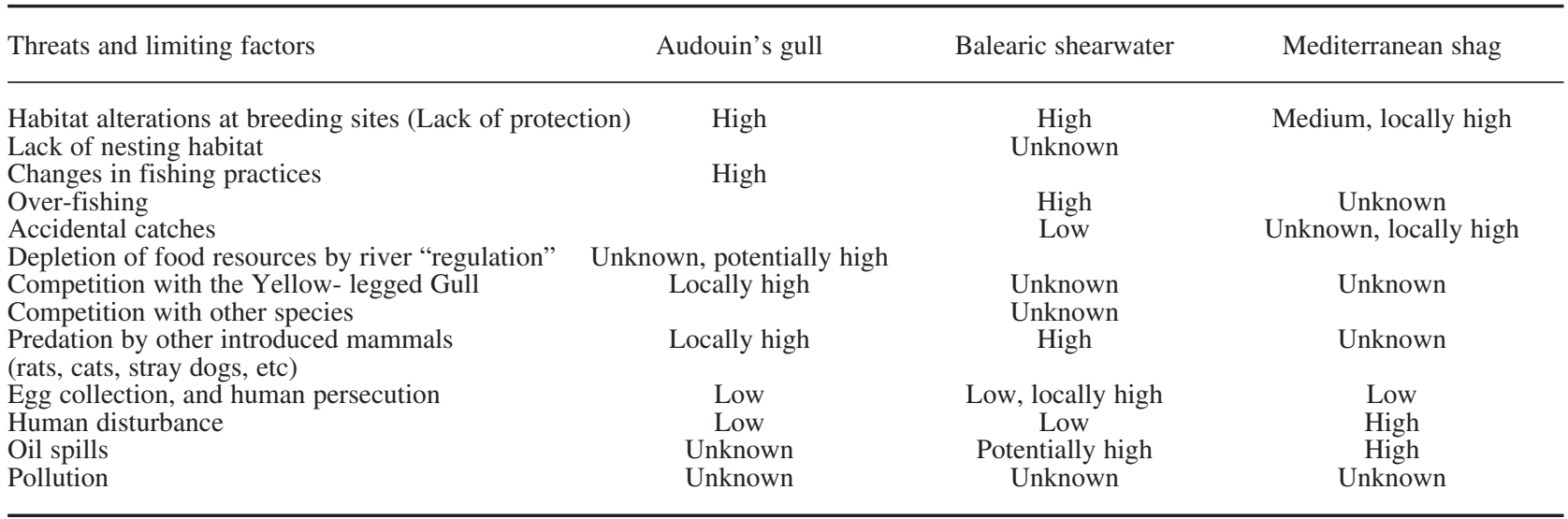

lowing headings:

- Policy and legislation

- Species and habitat protection

- Monitoring and research

- Public awareness.

Each objective is broken down into a series of actions followed by a brief description. These actions are generic and do not make reference to any particular country or geographical region except in special cases. Each action is given a priority rating and a time-scale in which it ought to be carried out using the following categories:

- Essential, an action that is needed to prevent a large decline in the population which could lead to the species or sub-species extinction

- High, an action that is needed to prevent a decline of more than $20 \%$ of the population in 20 years or less

- Medium, an action that is needed to prevent a decline of less than $20 \%$ of the population in 20 years or less

- Low, an action that is needed to prevent local population declines or that is likely to have only a small impact on the population across the range

Time-scale:

- Immediate, completed within the next year

- Short, completed within the next 1-3 years

- Medium, completed within the next 1-5 years

- Long, completed within the next 1-10 years

- Ongoing, an action that is currently being implemented and should continue

- Completed, an action that was completed during preparation of the $\mathrm{AP}$

Priority actions for most countries within the species range, cross-referenced to the numbered objectives, are listed in an annex to each plan to act as a guide for the preparation of national action plans.
THE SPECIES ACTION PLANS FOR

AUDUOIN'S GULL, BALEARIC SHEARWATER AND MEDITERRANEAN SHAG

\section{Threats and limiting factors}

Main threats and limiting factors identified in the accion plans are summarised in Table 1. Although there are differences in the biology and distribution of these three species, a number of threats are common. Houses, hotels and marinas for tourism are spreading in many areas occupied by the species and can destroy the habitat as well as increase disturbance during the breeding season. For the Balearic shearwater historical and paleontological records suggest that the species was breeding in sites that have been abandoned and possibly the lack of breeding sites is a limiting factor. Food availability is considered a major cause of population fluctuations and mobility of seabirds (Hunt, 1972; Springer et al., 1986). The increase in numbers at the Audouin's gull colony in the Ebro delta is apparently linked to the exploitation of fish waste dumped from boats fishing nearby (Beaubrun, 1983; Oro and MartínezVillalta, 1994). The industrial use of fish waste to produce animal food, as occurs in other areas of the Mediterranean, could pose a great and immediate threat to the maintenance of the colony at the Ebro delta, which relies largely on this food resource. Data about accidental capture of seabirds in long lines and fishing nets is scarce. In the Balearic Islands the accidental bycatch seems to affect Puffinus less than Calonectris. Some fishing methods such as gill nets and fish traps, particularly when located permanently close to the sea shore, are responsible for killing significant numbers of Mediterranean shags, as has been reported in 
Balearic Islands (Aguilar, 1991). Interaction with the yellow-legged gull (Larus cachinnans) has been recognised as a limiting factor for Audouin's gull in several Mediterranean colonies. This includes competition for nesting sites and predation of eggs (Oro and Martínez-Villalta, 1994b) and predation of nestlings and adults (Bradley, 1986; Monbailliu and Torre, 1986).

In 38 colonies of Balearic shearwaters studied, significant trends have been found, suggesting that there is competition for nest cavities and that Cory's shearwater (Calonectris diomedea) is dominant (Capellà, 1988).

Predation of chicks and eggs by rats is well documented for Mediterranean shearwater (Puffinus yelkouan) (Fernandez, 1979; Mayol, 1986). Balearic shearwaters breed on many islets colonised by rats, often with medium or high breeding success. Probably the effect of rat predation is more important on the smaller islets, where rodents reach higher densities. Stray cattle and dogs can also damage nests and young, and this is a big problem in several Italian colonies of Audouin's gull. Rats, foxes (Vulpes vulpes), cats and some reptiles can also pose a threat to the species.

Direct human impact such as the killing and/or collecting of eggs and chicks of Audouin's gull by local people and fishermen was formerly widespread but at present is of very little significance, although Audouin's gull eggs are still highly regarded in North Africa for confectionery. The harvesting of shearwaters was frequent until the late sixties, in Pitiusas (Ibiza and Formentera) (Mayol, 1985). Mainly the adults were collected because many pulli occupied inaccessible holes. From 2,400 to 2,700 adults per year were taken in Formentera until the 1960s. The increase in the human standard of living has resulted in a decrease in this practice, with probably fewer than 100 adults/year harvested. Although the species has been protected since the seventies, it is certain that some colonies are still harvested.

The breeding period of Audouin's gull overlaps with the tourist season on the Mediterranean coasts, and the increasing disturbance which this causes may represent a major future hazard for the species (Mayol, 1986; Thibault and Guyot, 1989) and for other syntopic seabirds. The easy accessibility of many colonies and the conspicuousness of the gulls and shag make them very vulnerable to disturbance by tourists, either by boating near the shore or by direct intrusion on the nesting areas. Birdwatching and research activities can also cause disturbance.
Illegal fishing with dynamite may be a problem locally. The use of lights for some fishing practices close to the colonies can negatively affect the behaviour of breeding Balearic shearwaters. Ambient light near important colonies can affect also adult behaviour and cause dazzling of fledglings. Mediterranean shag is a shy bird which is severely affected by frequent visits to the colonies. (Guyot, 1993). These threats are not only limited to colonies but also apply at roosting places. Despite legal protection, illegal prosecution of the Mediterranean shag is still frequent in some areas.

The high level of recorded oil pollution in the Mediterranean from incidental oil spills or illegal washing of tanks could have lethal and sublethal effects on adults and eggs through eggshell smearing. A serious oil spill during the breeding season near breeding colonies could be disastrous for Audouin's gull, while Balearic shearwaters gather in coastal areas near important harbours during moult and become very vulnerable to oil spills

Chemical contamination is heavy in Mediterranean waters and represents a serious hazard for seabirds (Lambertini and Leonzio, 1986). High levels of heavy metals and chlorinated hydrocarbons (including dioxins, coplanar PCBs and dibenzofurans) have been found in Audouin's gull samples. High mercury levels were found in chicks in Asinara (Sardinia), and for several years the colony had a very low breeding success which finally led to its total disappearance.

\section{Actions}

The full list of actions and their priorities as identified by the experts compiling the action plans are given in Annex I. More general work areas which are common for all the three species are presented in Table 2. Action plans identify the need to influence fishery activities through EU policies as well as to undertake actions at national and local levels to reduce the impact of fishing on seabird species.

International and national legislation must be strengthened in order to reduce the level of oil and chemical pollution which affects the Mediterranean basin and is known to have negative impacts on the reproduction and survival of the species. The development of National Biodiversity and, more specifically, of coastal strategies, is the basis for a sustainable development of the Mediterranean coasts. Recommendation $\mathrm{N}^{\circ} 62$ of the Standing Committee of the Bern Convention calls the contracting parties to 
TABLE 2. - Overview of the actions identified in the Species Action Plans.

\author{
National and international legislation \\ Influence EU policies (fishery) \\ Prevent oil spill and pollution \\ Develop National Coastal Strategies \\ Develop National Action Plans \\ Protect the species and its habitat through national and \\ international legislation \\ Birds Directive (SPA) and Habitat directive (SIC) which \\ will become \\ Nature 2000 Network \\ Barcelona Convention (MedSPA) \\ Biodiversity Convention (National Strategies) \\ Bern Convention (Rec. no. 62) \\ Promote international co-operation
}

\section{Species and habitat protection}

Ensure adequate protection of the species

Designation of key sites as Protected areas

Undertake appropriate management

Prevent disturbance and persecution

Control of competitors and predators (yellow-legged gull, rats, etc.)

\section{Research and monitoring}

Develop or continue monitoring of the population

Study population dynamics

Habitat requirement

Feeding ecology

Movement

Locate new breeding sites/wintering or passage areas

Limiting factors

Fishery

Disturbance

Competitors/predators

\section{Public awareness}

Promote exchange of information

Awareness campaigns targeting specific groups and the general public

develop national action plans for the species as a tool for proper implementation of their conservation. Key sites, identified through the IBA programme should become part of the Natura 2000 (EU) and Emerald (Council of Europe) networks, should be declared SPAMI (Barcelona Convention), become protected areas and be properly managed to reduce disturbance predation and to stop habitat loss.

Our knowledge on the distribution, ecology and movements of the species needs to be increased in order to identify, protect and monitor all key sites. Research needs to be carried out on the impact on seabirds of a number of factors, such as fishery, disturbance, interspecific competition or predation, which have been identified as actual or potential threats.

Exchange of information among researchers and conservationists must be continued and possibly improved and the Benidorm meeting is a good example of the implementation of this objective.
Finally, local communities, as well as decisionmakers, fishermen and tourists need to be made aware of the need to protect these species and their habitat through specific awareness and educational campaigns since all too often lack of knowledge is the reason for incorrect behaviour or activities.

\section{CONCLUSIONS}

The Species Action Plans provide all necessary information for planning and carrying out conservation activities for each species at all level. They are common documents which NGOs and Governmental agencies should agree to use as a base for common or co-ordinated work based on priority and urgency. They are "living documents" which provide a sound international background for developing more detailed national or local plans for actions covering all useful activities aimed at the conservation of the most endangered bird species in Europe.

\section{REFERENCES}

Aguilar, J.S. - 1991. Resum de l'Atlas d'ocells marins de les Balears, 1991. In: G.O.B. (ed.), Anuari Ornitológic de les Balears. Vol 6., pp 17-28. Palma de Mallorca.

Beaubrun, P.-C. - 1983. Le Goéland d'Audouin (Larus audouinii Payr.) sur les cotes du Maroc. Oiseau et R.F.O., 53: 209-226.

BirdLife International. - 2000. Threatened Birds of the World. Lynx Edicions and BirdLife International, Barcelona and Cambridge.

Bradley, P. - 1986. The breeding biology of Audouin's Gull on the Chafarinas Islands. In: MEDMARAVIS and X. Monbailliu (eds.), Mediterranean marine avifauna, pp. 221-230. Berlin and Heidelberg: Springer-Verlag (NATO ASI Ser. G. 12).

Capellà, Ll. - 1988. Observaciones sobre la pardela pichoneta (Puffinus puffinus mauretanicus) de las Baleares. In: C. LópezJurado (ed.), Aves Marinas, pp. 61-68. Actas IV Reunión del GIAM. GOB. Palma de Mallorca.

Collar, N.J., M.J. Crosby and A.J. Stattersfield. - 1994. Birds to watch 2: the world list of threatened birds. BirdLife International (BirdLife Conservation Series, 4), Cambridge.

Fernandez, O. - 1979. Observations sur le Puffin Cendré Calonectris diomedea nicheur sur les iles marsellaises. Alauda, 47: 6572.

Guyot, I. - 1993. Breeding distribution and number of shag (Phalacrocorax aristotelis desmarestii) in the Mediterranean. In: Aguilar, J.S., X. Monabailliu and A.M. Paterson (eds.), Estatus y Conservación de Aves Marinas, pp. 37-46. Actas del II Simposio MEDMARAVIS. SEO, Madrid.

Heath, M.F. and M.L. Evans (eds.). - 2000. Important Bird Areas in Europe: Priority sites for conservation. 2 vols. BirdLife International (BirdLife Conservation Series No. 8), Cambridge, UK.

Heredia, B., L. Rose and M. Painter. - 1996. Globally threatened birds in Europe. Action plans. Council of Europe / BirdLife International, Strasbourg.

Hunt, G.L. - 1972. Influence of food distribution and human disturbance on the reproductive success of Herring Gulls. Ecology, 53: 1051-1061.

Lambertini, M. and C. Leonzio. - 1986. Pollutant levels and their effects on Mediterranean seabirds. In MEDMARAVIS and X. Monabailliu (eds.), Mediterranean Marine Avifauna, pp 359- 
378. Springer-Verlag. Berlin-Heidelberg.

Mayol, J. - 1985. La conservació de la natura a les illes Pitiüses. Estudis Balearics, 16:

Mayol, J. - 1986. Human impact on seabirds in the Balearic Islands. In: MEDMARAVIS and X. Monbailliu (eds.), Mediterranean marine avifauna, pp.379-396. Berlin and Heidelberg: SpringerVerlag (NATO ASI Ser. G. 12)

Monbailliu, X. and A. Torre. - 1986. Nest-site selection and interaction of Yellow-legged and Audouin's Gulls at Isola dell'Asinara. In: MEDMARAVIS and X. Monbailliu (eds.), Mediterranean marine avifauna, pp.245-263. Berlin and Heidelberg: Springer-Verlag (NATO ASI Ser. G. 12).

Oro, D. and A. Martínez-Vilalta. - 1994a. Migration and dispersal of Audouin's Gull Larus audouinii from the Ebro delta colony. Ostrich, 65: 225-230.

Oro, D. and A. Martínez-Vilalta. - 1994b. Factors affecting klep- toparasitism and predation rates upon a colony of Audouin's Gull (Larus audouinii) by Yellow-legged Gulls (Larus cachinnans). Colon. Waterbirds, 17: 35-41.

Springer, A.M., D.G. Roseneau, S.L. Denby, C.P. McRoy and E.C Murphy. -1986 . Seabird responses to fluctuating prey availability in the eastern Bering Sea. Mar. Ecol. Prog. Ser., 32: 1-12.

Thibault, J. C. and I. Guyot. - 1989. Le Goéland d'Audouin en Corse: synthèse pour la gestion d'une éspece menacée. Ajaccio: Association des Amis du Parc Naturel Regional Corse.

Tucker, G.M. and M.I. Evans. - 1997. Habitats for birds in Europe. A conservation strategy for the wider environment. BirdLife International (BirdLife Conservation Series, 6), Cambridge, UK.

Tucker, G.M. and M.F. Heath. - 1994. Birds in Europe: their conservation status. BirdLife International (BirdLife Conservation Series, 3), Cambridge, UK. 
AnNex I. - Summary of the actions identified in the Species Action Plans

\begin{tabular}{|c|c|c|c|c|c|}
\hline Audouin's gull & priority & Balearic shearwater & priority & Mediterranean shag & priority \\
\hline $\begin{array}{l}\text { 1.1. To influence EU fisheries } \\
\text { policies and regulations for the } \\
\text { benefit of biodiversity } \\
\text { conservation in the Mediterranean }\end{array}$ & high & $\begin{array}{l}\text { 1.4 EU fishery policies should } \\
\text { include considerations on } \\
\text { seabirds, taking into account } \\
\text { the impact on its populations. }\end{array}$ & high & $\begin{array}{l}1.1 \text { To influence policies in } \\
\text { the Mediterranean }\end{array}$ & high \\
\hline \multirow[t]{2}{*}{$\begin{array}{l}\text { 1.2. To develop National } \\
\text { Coastal Strategies }\end{array}$} & medium & $\begin{array}{l}1.1 \text { To develop national } \\
\text { coastal strategies }\end{array}$ & medium & $\begin{array}{l}1.2 \text { To develop national } \\
\text { coastal strategies }\end{array}$ & medium \\
\hline & & & & $\begin{array}{l}1.3 \text { To ensure that the } \\
\text { Mediterranean shag and its } \\
\text { habitat receive full protection } \\
\text { through national and } \\
\text { international legislation. }\end{array}$ & high \\
\hline
\end{tabular}

\begin{tabular}{llll}
\hline $\begin{array}{l}\text { 1.3. To ensure that Audouin's } \\
\text { gull and its habitat receive full } \\
\text { protection through national }\end{array}$ & high $\quad \begin{array}{l}1.3 \text { To ensure the protection } \\
\text { of the breeding habitat }\end{array}$ & high & $\begin{array}{l}\text { 1.3.1. To promote proper } \\
\text { implementation of the } \\
\text { Habitats Directive }\end{array}$
\end{tabular}

1.3.2. To promote proper implementation of the Birds Directive

1.3.3 To encourage the establishment of buffer zones surrounding breeding areas including the adjacent sea area

\begin{tabular}{|c|c|c|c|c|c|}
\hline $\begin{array}{l}\text { 1.4. To prevent chemical } \\
\text { pollution of the sea and oil spills }\end{array}$ & high & $\begin{array}{l}1.2 \text { To prevent oil spills and } \\
\text { chemical pollution of the sea }\end{array}$ & high & $\begin{array}{l}\text { 1.4 To prevent oil spills and } \\
\text { chemical pollution of the sea }\end{array}$ & high \\
\hline $\begin{array}{l}\text { 1.5. To promote the preparation } \\
\text { of national action plans }\end{array}$ & high & $\begin{array}{l}\text { 1.5.3 Recommendation No. } 62 \\
\text { on the conservation of regionally } \\
\text { threatened birds in the Macaronesian } \\
\text { and Mediterranean regions, of the } \\
\text { Standing Committee of the Bern } \\
\text { Convention, promotes the drafting } \\
\text { and implementation of Action Plans } \\
\text { for Mediterranean most threatened } \\
\text { species that are not globally threatened. }\end{array}$ & high & $\begin{array}{l}1.5 \text { To promote the preparation } \\
\text { of National Action Plans }\end{array}$ & high \\
\hline
\end{tabular}

1.6. To involve international conventions in the conservation of the species and its habitat medium

1.5 To involve international
conventions in the conservation of the
Balearic shearwater and its habitat

1.5.1 The Barcelona Convention should seek to include all the important colonies and the areas where the species congregates in the Mediterranean SPAs.

1.5.2 National strategies drawn up under the Biodiversity Convention should promote the conservation and sustainable management of coastal and island ecosystems.

1.6. The new taxonomic status of the high species must be included in future reviews of international conventions.

\section{high}

1.6 To involve international conventions in the conservation of the species and its habitat

1.6.1. The Barcelona Convention should seek to include all the important colonies and the areas where the species congregates outside the breeding season in the Mediterranean SPAs.

1.62 National strategies drawn up under the Biodiversity Convention should promote the conservation and sustainable management of coastal and island ecosystems.

1.7. To promote international high
cooperation and funding from
bilateral agencies

cooperation and funding from bilateral agencies
2.1. To ensure adequate protection high of breeding sites and remove major threats to breeding habitat

\subsubsection{To designate all key sites} as protected areas
2.1 To ensure adequate protection of breeding sites. All the IBAs and protected areas where Balearic shearwater occurs should include specific measures for its effective conservation.
1.7 To promote international cooperation and funding for research, monitoring and conservation from bilateral agencies

high $\quad 2.1$ To ensure adequate protection of breeding sites. All the IBAs and protected areas where shag occurs should include specific measures for effective shag protection 
AnNeX I. (Cont.) - Summary of the actions identified in the Species Action Plans

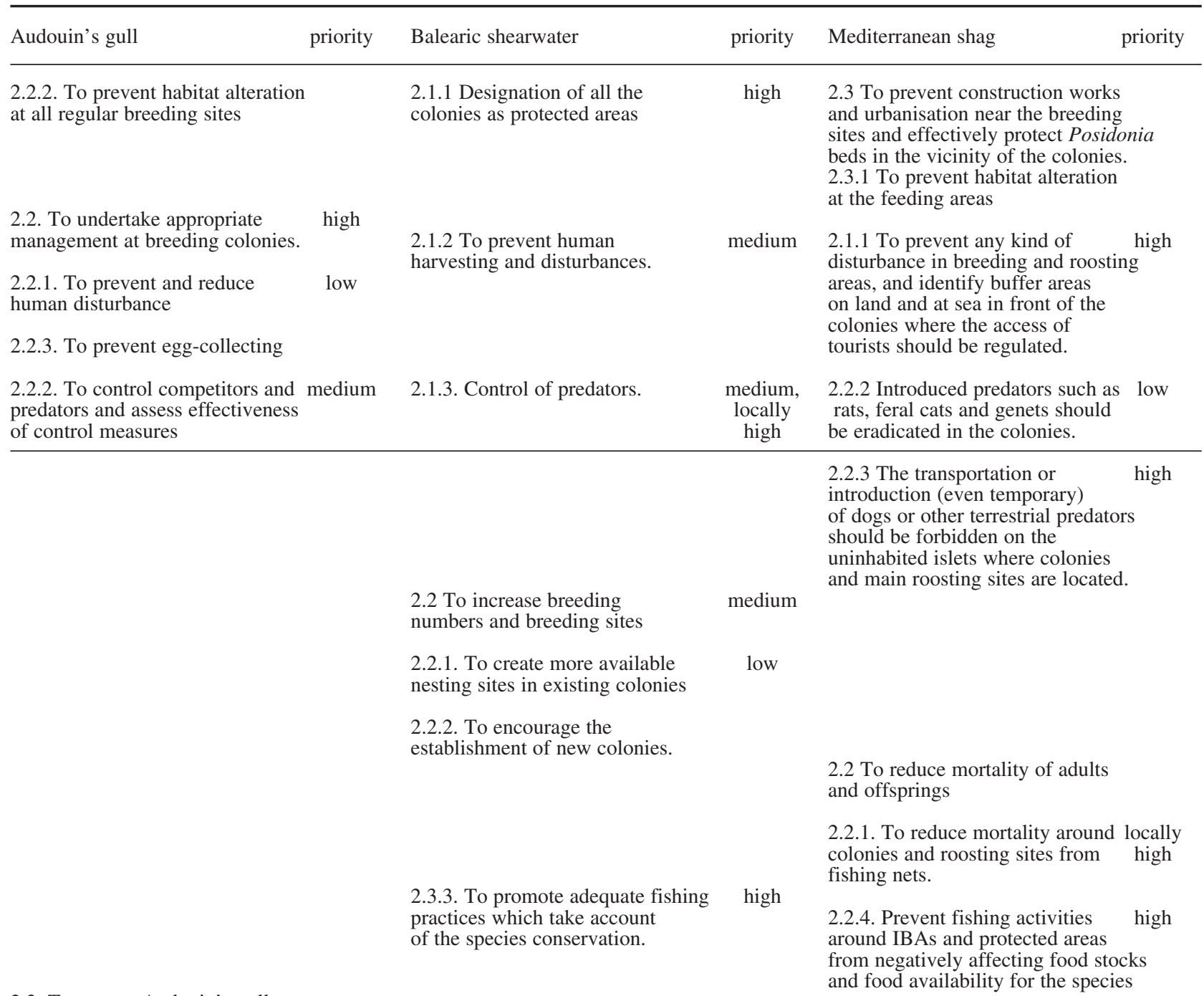

2.3. To protect Audouin's gull

and its habitat in the winter quarters

and along the migration route

2.3.1. To seek protection for all $\mathrm{r}$ medium egular wintering sites

3.1. To set up and implement a monitoring programme

3.1.1. To monitor population status and range trends

3.3.1. To study population dynamics

3.1.2. To determine current distribution and population status

3.1.3. To determine the extent and location of discrete populations

\begin{tabular}{llll}
\hline $\begin{array}{l}\text { 3.2.2. Feeding ecology and } \\
\text { habitat use in winter }\end{array}$ & $\begin{array}{l}\text { medium/ } \\
\text { high }\end{array}$ & $\begin{array}{l}3.2 \text { To undertake research on } \\
\text { feeding ecology over the whole } \\
\text { species range }\end{array}$ & $\begin{array}{l}3.2 .2 . \text { Feeding ecology and } \\
\text { habitat use }\end{array}$ \\
$\begin{array}{l}\text { 3.3.3. To determine the diet in medium } \\
\text { different parts of the Mediterranean }\end{array}$ & $\begin{array}{l}3.2 .1 \text { To identify the most } \\
\text { important prey items and feeding sites }\end{array}$ & high \\
\hline
\end{tabular}

$\begin{array}{lll}\begin{array}{l}\text { 3.1. To continue the } \\ \text { monitoring programme. }\end{array} \quad \text { medium } & \begin{array}{l}\text { 3.1. To set up and implement a } \\ \text { monitoring programme }\end{array} & \text { high }\end{array}$

3.2. To undertake research on ecology

high 3.2.1 Population dynamics high medium

\section{high}

high 3.3.1. Population dynamics high

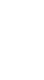

2.1.1 Designation of all the colonies as protected areas and food availability for the species 
AnNex I. (Cont.) - Summary of the actions identified in the Species Action Plans

\begin{tabular}{|c|c|c|c|c|}
\hline Audouin's gull & Balearic shearwater & priority & Mediterranean shag & priority \\
\hline $\begin{array}{l}\text { 3.2. To undertake research on } \\
\text { dispersal patterns and winter ecology }\end{array}$ & 3.2.2 Food availability monitoring. & high & 3.2.3. Seasonal movements & low \\
\hline $\begin{array}{l}\text { 3.2.1. To identify the most } \\
\text { important passage sites and } \\
\text { wintering areas }\end{array}$ & & & & \\
\hline
\end{tabular}

3.3. To promote research which is directly applicable to the conservation and management of Audouin's gull

3.3.2. To undertake comparative medium studies of breeding biology and colony-site selection in different habitats

3.4. To assess major threats and their effects

3.3 To promote studies with direct application to the conservation and management of the species

\subsubsection{Chemical pollution medium and oil spills}

\subsubsection{Fishing policies}

3.4.3. Habitat requirements

3.4.4. Human disturbance

3.4.5. Competitors

3.4.6. Predators

3.4.7. To monitor fishing activities for possible impact on breeding and wintering Audouin's gulls

\section{high}

medium

3.5. To agree a protocol for low-disturbance monitoring and research

\subsection{To promote information exchange}

4.1. To provide information and increase awareness

\begin{abstract}
4.1.1. To increase awareness about Audouin's gull among politicians and decision-makers
\end{abstract}

4.1.3. To involve tourists and fishermen in preventing disturbance

4.1.2. To inform the general public about the plight of Audouin's gull

4.1.4. To prepare and distribute educational material

4.1.5. To use the media to increase awareness

4.2. To use Audouin's gull as a flagship species medium 3.3.2 Impact of human disturbance medium

medium $\quad 3.3 .3$ To assess the impact of low

medium $\quad 3.3 .4$ Predators at breeding sites

high 3.3.5 Accidental catches medium 3.2.5 Effect of fisheries high
3.2.4 Limiting factors 
